\title{
KEMAMPUAN PEMAHAMAN MATEMATIS SISWA KELAS VII SMP PADA MATERI HIMPUNAN MELALUI MODEL DISCOVERY LEARNING
}

\author{
Marwia Tamrin Bakar', Karman Lanani' ${ }^{1}$, Yulyanti Harisman², Asep Amam ${ }^{3}$ \\ 1 Universitas Khairun, Jl.Bandara Sultan Babullah Kode Pos 53, Ternate, Indonesia \\ 2 Universitas Negeri Padang, Jl. Prof. Dr. Hamka, Air Tawar Bar., Kec. Padang Utara Sumatera Barat, 25171 Indonesia \\ 3 Universitas Galuh, Jl.R. E. Martadinata No 150, Ciamis, Jawa Barat, Indonesia \\ Email: tmarwia@gmail.com
}

\begin{abstract}
The discovery learning model is one of four models recommended by the 2013 curriculum as innovative learning models capable of developing attitude, knowledge, and skills skills. In its application, the discovery learning model directs students to be able to find information and understand concepts that are learned independently based on their abilities with teacher guidance and supervision. The use of discovery learning models, is expected to be an alternative to improving students' mathematical ability to understand set materials. The subjects in this study were 32 grade VII-A students of one of the State Junior High Schools in Ternate City. The study used a one sample pretest-postest design. Data on students' mathematical understanding skills is obtained through learning process activities and formative tests of set materials after the application of discovery learning models. The results of the student's mathematical comprehension test found that there were 19 students (59.37\%) achieved a "very good" qualification, 9 students $(28.13 \%)$ qualifications, and 4 students $(12.50 \%)$ in sufficient qualifications. Attainment of students' mathematical understanding skills, there are 28 students $(87.50 \%)$ completed, and 4 students $(12.50 \%)$ have not achieved completed in learning mathematics on the set material. The application of discovery learning model can significantly improve the mathematical understanding ability of grade VII-A students of one of the State Junior High Schools in Ternate City in the set material.
\end{abstract}

Keywords: Discovery learning model, mathematical understanding, set material

\begin{abstract}
ABSTRAK
Model discovery learning adalah salah satu model diantara empat model yang direkomendasikan oleh kurikulum 2013 sebagai model pembelajaran inovatif yang mampu mengembangkan kemampuan sikap, pengetahuan, dan keterampilan. Dalam penerapannya, model discovery learning mengarahkan siswa agar mampu menemukan informasi dan memahami konsep yang dipelajari secara mandiri berdasarkan kemampuan yang dimilikinya dengan bimbingan dan pengawasan guru. Penggunaan model discovery learning, diharapkan dapat menjadi alternatif untuk meningkatkan kemampuan matematis siswa dalam memahami materi himpunan. Subjek dalam penelitian ini adalah 32 orang siswa kelas VII-A salah satu SMP Negeri di Kota Ternate. Penelitian ini menggunakan desain one sample pretest-postest. Data kemampuan pemahaman matematis siswa diperoleh melalui aktivitas proses pembelajaran dan tes formatif materi himpunan setelah penerapan model discovery learning. Hasil tes kemampuan pemahaman matematis siswa diperoleh hasil bahwa terdapat 19 orang siswa $(59,37 \%)$ mencapai kualifikasi "baik sekali", 9 orang siswa $(28,13 \%)$ mencapai kualifikasi baik, dan 4 orang siswa $(12,50 \%)$ dalam kualifikasi cukup. Pencapaian kemampuan pemahaman matematis siswa, terdapat 28 orang siswa $(87,50 \%)$ mencapai ketuntasan, dan 4 orang siswa $(12,50 \%)$ belum mencapai ketuntasan dalam belajar matematika pada materi himpunan. Penerapan model discovery learning secara signifikan dapat meningkatkan kemampuan pemahaman matematis siswa kelas VII-A salah satu SMP Negeri di Kota Ternate pada materi himpunan.
\end{abstract}

Kata kunci: Himpunan, kemampuan pemahaman matematis, model discovery learning

Dikirim: 24 Februari 2020; Diterima: 25 Agustus 2020; Dipublikasikan: 30 September 2020

Cara sitasi: Bakar, M. T., Lanani. K., Harisman. Y., \& Amam, A. (2020). Kemampuan pemahaman matematis siswa kelas vii smp pada materi himpunan melalui model discovery learning. Teorema: Teori dan Riset Matematika, 5(2), 271-279. 


\section{PENDAHULUAN}

Discovery learning merupakan pembelajaran yang menciptakan aktivitas siswa untuk membaca materi melalui sumber belajar atau bahan ajar, mengumpulkan informasi bermakna yang relevan, mendiskusikan data informasi hasil pengumpulannya, melakukan verifikasi kebenaran informasi materi sesuai sumber, mempertanggungjawabkan hasil temuannya, dan menyimpulkan hasil belajarnya (Faturrahman, 2015). Skenario penerapan model discovery learning mengarahkan siswa memecahkan masalah nyata secara mandiri dan kelompok berdasarkan informasi yang dipelajarinya melalui buku sumber atau bahan ajar yang diberikan. Menurut Alma et al. (2010: 59), model discovery learning juga disebut sebagai pendekatan inkuiri bertitik tolak pada suatu keyakinan dalam rangka perkembangan siswa secara independen. Model ini membutuhkan partisipasi aktif dalam penyelidikan secara ilmiah. Hal ini sejalan dengan pendapat bahwa "Discovery learning can be defined as the learning that takes place when the student is not presented with subject matter in the final form, but rather is required to organize it himself' (Lefancois dalam Emetembun, 1986:103 dalam Kemendikbud 2014).

Menurut Borthick \& Jones (2000) bahwa dalam pembelajaran discovery siswa belajar untuk mengenali masalah, mencari solusi, mencari informasi yang relevan, mengembangkan strategi solusi, dan melaksanakan strategi yang dipilih. Kolaborasi pembelajaran penemuan, siswa tenggelam dalam komunitas praktek, memecahkan masalah secara bersama-sama. Hoffman (2000) menyatakan bahwa belajar discovery adalah strategi instruktur yang dapat dimanfaatkan untuk meningkatkan keterlibatan dan relevansi siswa. Ada lima belajar penemuan yang terdiri dari: pembelajaran berbasis kasus, belajar incidental, belajar dengan menjelajahi, belajar dengan refleksi, dan pembelajaran simulasi berbasis sendiri, atau dalam kombinasi, yang dapat diterapkan untuk kegiatan dan pengajaran keterampilan. Depdikbud (2014: 14) mengungkapkan bahwa discovery learning mempunyai prinsip yang sama dengan inkuiri (inquiry). Discovery learning menekankan pada ditemukannya konsep atau prinsip yang sebelumnya tidak diketahui. Discovery memperhadapkan masalah hasil rekayasa guru kepada siswa, sedangkan inkuiri memperhadapkan masalah yang sebenarnya (bukan hasil rekayasa), sehingga siswa harus mengerahkan seluruh pikiran dan keterampilannya untuk mendapatkan temuan-temuan didalam masalah itu melalui proses penelitian.

Trianto (2007) menyatakan bahwa terdapat 6 (enam) tahapan penerapan model discovery learning, meliputi: (1) stimulation (stimulasi/pemberian rangsangan); (2) problem statement (pernyataan/identifikasi masalah); (3) data collection (pengumpulan data); (4) data processing (identifikasi relevansi masalah dengan bahan pelajaran); (5) verification (pembuktian); dan (6) generalization (menarik kesimpulan). Berdasarkan tahapan pembelajaran tersebut dikembangkan perangkat pembelajaran untuk menciptakan suasana pembelajaran yang mendorong peningkatan kemampuan pemahaman matematis siswa dalam pembelajaran matematika.

Penerapan model discovery learning yang mengarahkan siswa untuk melakukan pengembangan belajar siswa secara individu dan kelompok yang memungkinkan siswa merekontruksi pengetahuan matematika untuk diterapkan dalam kehidupan nyata. Menurut Hudojo (Rahmawati, 2011: 18), pembelajaran matematika membutuhkan pemahaman konsep dan penguasaan materi matematika. Kemampuan pemahaman matematis siswa terhadap setiap materi yang diajarkan guru penting dimiliki oleh setiap siswa karena dapat membantu proses mengingat dan membuat lebih mudah untuk menyelesaikan masalah matematika dalam kehidupan nyata.

Penelitian ini berupaya mengungkapkan kemampuan pemahaman matematis siswa pada materi himpunan melalui penerapan model discovery learning. Menurut Bakar et al. (2018); Bakar (2018) pemahaman matematika adalah kemampuan dasar dalam belajar matematika yang merupakan suatu proses konstruksi mental yang menghubungkan, membuat generalilsasi dan mensintesis representasi internal dan eksternal dari objek matematika. Selanjutnya Bakar et al. (2020) menjelaskan bahwa siswa harus memiliki kemampuan pemahaman konsep matematika ketika belajar matematika, karena matematika yang bersifat abstrak dan terdiri atas simbol-simbol, 
membuat matematika dianggap rumit oleh sebahagian siswa. Afrilianto (2012), menyatakan bahwa kemampuan pemahaman matematis adalah salah satu tujuan penting dalam pembelajaran, memberikan pengertian bahwa materi-materi yang diajarkan kepada siswa bukan sebagai hafalan, namun siswa dapat memahami konsep pelajaran secara mandiri melalui kolaborasi dengan sumber belajar. Polya (Sumarmo, 2013) menggolongkan pemahaman matematis dalam empat tingkatan, yaitu: (1) pemahaman mekanikal, siswa dapat melaksanakan perhitungan rutin atau sederhana; (2) pemahaman induktif, siswa dapat mencobakan sesuatu dalam kasus sederhana dan tahu bahwa sesuatu itu berlaku dalan kasus serupa; (3) pemahaman rasional, siswa dapat membuktikan kebenaran sesuatu; dan (4) pemahaman deduktif, siswa dapat memperkirakan kebenaran sesuatu tanpa ragu-ragu, sebelum menganalisis secara analitik. Dewiatmini (2010) menyatakan bahwa siswa dikatakan memiliki kemampuan pemahaman matematis apabila mampu: (1) mendefinisikan konsep secara verbal dan tulisan; (2) membuat contoh dan bukan contoh suatu konsep; (3) mempresentasikan suatu konsep dengan model, diagram, dan simbol; (4) mengubah suatu bentuk representasi ke bentuk lain; (5) mengenal sebagai makna dan interpretasi konsep; (6) mengidentifikasi sifat-sifat dan mengenal syarat-syarat yang menentukan suatu konsep; dan (7) membandingkan dan membedakan konsep-konsep yang dipelajarinya.

Kemampuan pemahaman matematis siswa diukur dengan indikator capaian agar siswa dapat mengenal, memahami, menerapkan, menyajikan, mengaitkan konsep, menyajikan, prosedur, prinsip dan ide matematika pada materi himpunan. Permasalahan penelitian ini dirumuskan dalam bentuk pertanyaan: (1) bagaimana kemampuan pemahaman matematis siswa pada materi himpunan melalui penerapan pembelajaran dicovery learning?; dan (2) apakah penerapan model discovery learning secara signifikan dapat meningkatkan kemampuan pemahaman matematis siswa dalam mempelajari materi himpunan?. Penelitian ini diharapkan meningkatkan aktivitas siswa dalam mengeksplorasi kemampuan pemahaman matematis secara mandiri dan dapat menjadi informasi bagi penelitian selanjutnya.

\section{METODE PENELITIAN}

Penelitian kuasi eksperimen ini menggunakan desain one sample pretest-postest (Sugiyono. 2015) dengan menjadikan 32 siswa kelas VIIA SMP Negeri 1 Kota Ternate sebagai subyek penelitian. Data kuantitatif diperoleh melalui tes kemampuan pemahaman matematis siswa dan data kualitatif berdasarkan hasil observasi aktivitas guru dan siswa, serta hasil wawancara siswa. Data yang diperoleh dianalisis secara deskriptif dan inferensial untuk memberikan interpretasi dan kesimpulan sehubungan dengan kemampuan pemahaman matematis siswa dalam mempelajari materi himpunan serta peningkatannya. Statistik deskriptif berdasarkan pendekatan acuan patokan (PAP) dan gain ternormalisasi, untuk menggambarkan pencapaian dan peningkatan kemampuan pemahaman matematis siswa pada materi himpunan setelah diterapkan model discovery learning. Statistik inferensial menggunakan uji perbedaan rata-rata kemampuan pemahaman matematis siswa antara sebelum dan sesudah penerapan model discovery learning. Uji ini dimaksudkan untuk menjawab bahwa penerapan model discovery learning secara signifikan dapat meningkatkan kemampuan pemahaman matematis siswa kelas VII A SMP Negeri 1 kota Ternate pada materi himpunan.

\section{HASIL DAN PEMBAHASAN}

Hasil penelitian ini diuraikan untuk menjawab permasalahan, mengetahui tercapainya tujuan penelitian, dan menggambarkan bahwa penerapan model discovery learning secara signifikan dapat meningkatkan kemampuan pemahaman matematis siswa kelas VIIA SMP Negeri 1 Kota Ternate dalam mempelajari materi himpunan. Uraian data hasil penelitian difokuskan untuk menjelaskan aktivitas guru dan siswa selama proses pembelajaran dan kemampuan pemahaman matematis siswa dalam mempelajari materi himpunan setelah diterapkan model discovery learning. Data hasil penelitian ini diperoleh melalui tes tertulis, observasi aktivitas guru dan siswa, serta wawancara. 


\section{Aktivitas Guru Selama Penerapan Model Discovery Learning}

Aktivitas guru dalam penerapan model discovery learning diperoleh dari hasil pengamatan observer berdasarkan pedomen observasi yang telah dipersiapkan. Pengamatan observer terhadap aktivitas guru, meliputi: perencanaan (persiapan perangkat pembelajaran), serta pelaksanaan model discovery learning (orientasi, stimulation, problem statement, data processing, verification, generalization, dan evaluation). Aktivitas guru dalam menerapkan model discovery learning dapat dijelaskan bahwa guru telah melakukan perencanaan pengajaran secara baik dengan mempersiapkan RPP, bahan ajar, dan LKPD yang berisi petunjuk dan soal latihan dengan baik. Selama pelaksanaan pembelajaran, guru menjalankan semua tahapan model discovery learning secara berurutan dan terlaksana dengan sangat baik. Penerapan model tersebut menciptakan siswa termotivasi untuk mengikuti proses pembelajaran, aktif mengkaji materi himpunan yang dipelajarinya, dan berusaha menemukan jawaban terhadap soal latihan yang dipersiapkan dalam LKPD.

\section{Aktivitas Siswa Selama Penerapan Model Discovery Learning}

Deskripsi aktivitas siswa selama penerapan model discovery learning disajikan pada Tabel 1.

Tabel 1. Deskripsi rata-rata aktivitas siswa

\begin{tabular}{|c|c|c|c|c|c|c|c|c|}
\hline \multirow{2}{*}{ No } & \multirow{2}{*}{ Aktivitas siswa } & \multicolumn{5}{|c|}{ Aktivitas belajar siswa/Pertemuan } & \multirow{2}{*}{ Jumlah } & \multirow{2}{*}{ Rata-rata } \\
\hline & & I & II & III & IV & V & & \\
\hline 1 & Orientasi & 2,50 & 3,00 & 3,40 & 3,60 & 3,91 & 16,50 & 3,30 \\
\hline 2 & Stimulation & 3,00 & 4,00 & 4,00 & 4,00 & 4,00 & 19,00 & 3,80 \\
\hline 3 & Problem statement & 2,00 & 2,00 & 3,00 & 3,00 & 3,00 & 13,00 & 2,60 \\
\hline 4 & Data collection & 1,67 & 2,33 & 2,33 & 3,00 & 3,33 & 12,67 & 2,53 \\
\hline 5 & Data processing & 2,50 & 3,00 & 3,00 & 3,50 & 3,50 & 15,50 & 3,10 \\
\hline 6 & Verification & 3,50 & 3,50 & 3,50 & 4,00 & 4,00 & 18,50 & 3,70 \\
\hline 7 & Generalization & 1,25 & 1,75 & 2,00 & 2,75 & 3,00 & 10,73 & 2,15 \\
\hline 8 & Penutup & 2,33 & 3,00 & 3,00 & 3,33 & 3,33 & 15,00 & 3,00 \\
\hline & Rata-rata & 2,34 & 2,82 & 3,03 & 3,39 & 3,51 & 15,11 & 3,02 \\
\hline
\end{tabular}

Berdasarkan Tabel 1 di atas, dapat dijelaskan bahwa: (1) aktivitas siswa selama pembelajaran dengan menggunakan model discovery learning mengalami peningkatan untuk setiap pertemuan. Secara keseluruhan aktivitas siswa dalam pembelajaran berada pada kategori baik; dan (2) aktivitas siswa kategori rendah pada tahapan generalization dan verification serta mencapai kategori tinggi pada tahapan stimulation.

\section{Kemampuan Pemahaman Matematis Siswa Selama Proses Pembelajaran}

Data kemampuan pemahaman matematis siswa kelas VIIA SMP Negeri 1 kota Ternate selama penerapan model discovery learning diambil berdasarkan hasil kerja soal latihan siswa pada lembar kerja peserta didik (LKPD), baik secara individu maupun kelompok. Hasil kerja siswa secara individu diuraikan pada Tabel 1, dan hasil kerja siswa secara kelompok diuraikan pada Tabel 2.

Tabel 2. Deskripsi rata-rata kemampuan pemahaman matematis (KPM) siswa kelas VIla SMP Negeri 1 kota Ternate secara individu berdasarkan LKPD

\begin{tabular}{cccccccc}
\hline \multirow{2}{*}{ No } & \multicolumn{1}{c}{ Statistik } & I & II & III & IV & V & \multirow{2}{*}{ Rata-rata } \\
\hline 1 & Skor minimum & 60,00 & 65,00 & 70,00 & 75,00 & 76,00 & 69,20 \\
2 & Skor maksimum & 85,00 & 90,00 & 90,00 & 90,00 & 90,00 & 89,00 \\
3 & Rata-rata & 76,80 & 80,50 & 85,25 & 86,59 & 87,87 & 83,41 \\
4 & Simpangan baku & 9,70 & 8,26 & 7,14 & 5,54 & 3,92 & 6,57 \\
5 & Koefisien variasi & 12,63 & 10,26 & 8,37 & 6,39 & 7,88 & 7,88 \\
\hline
\end{tabular}

Berdasarkan data Tabel 2, dapat dijelaskan bahwa: (1) skor maksimum kemampuan pemahaman matematis siswa selama lima pertemuan mengalami peningkatan dari skor rata-rata 60 meningkat menjadi 76 , dan secara keseluruhan rata-rata skor minimum mencapai 69,20 dalam kategori cukup; (2) skor maksimum kemampuan pemahaman matematis siswa mengalami peningkatan dari skor rata-rata 85 meningkat menjadi 90 , dan secara keseluruhan rata-rata skor maksimum mencapai 89 dalam kategori baik sekali; (3) rata-rata kemampuan pemahaman 
matematis siswa meningkat dari 76,80 menjadi 87,87 , dan secara keseluruhan mencapai 83,41 dalam kategori baik sekali; (4) simpangan baku kemampuan pemahaman matematis siswa mengalami penurunan dari 9,70 menjadi 3,92, dan secara keseluruhan mencapai 6,57 dalam kategori semakin cenderung seragam; dan (5) koefisien variasi kemampuan pemahaman matematis siswa mengalami penurunan dari $12,63 \%$ menjadi $7,88 \%$, dan secara keseluruhan mencapai $7,88 \%$ disebutkan semakin baik. Deskripsi hasil tes kemampuan pemahaman matematis secara berkelompok diuraikan pada Tabel 3.

Tabel 3. Deskripsi kemampuan pemahaman matematis (KPM) siswa kelas VIla SMP Negeri 1 kota Ternate secara berkelompok berdasarkan LKPD

\begin{tabular}{|c|c|c|c|c|c|c|c|c|}
\hline \multirow{2}{*}{ No } & \multirow{2}{*}{ Kelompok } & \multicolumn{5}{|c|}{ KPM Siswa/Pertemuan } & \multirow{2}{*}{ Rata-rata } & \multirow{2}{*}{ Keterangan } \\
\hline & & I & ॥ & III & IV & v & & \\
\hline 1 & Pertama & 85 & 90 & 85 & 90 & 90 & 88 & Baik sekali \\
\hline 2 & Ke-Dua & 80 & 85 & 85 & 85 & 90 & 85 & Baik sekali \\
\hline 3 & Ke-Tiqa & 90 & 90 & 90 & 90 & 90 & 90 & Baik sekali \\
\hline 4 & Ke-Empat & 75 & 75 & 80 & 80 & 80 & 78 & Baik \\
\hline \multirow[t]{2}{*}{5} & Ke-Lima & 75 & 80 & 80 & 85 & 90 & 82 & Baik sekali \\
\hline & Skor minimum & 75 & 75 & 80 & 80 & 80 & 78 & Baik \\
\hline \multirow{4}{*}{ 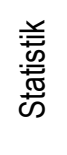 } & Skor maksimum & 90 & 90 & 90 & 90 & 90 & 90 & Baik sekali \\
\hline & Rata-rata & 81 & 84 & 84 & 86 & 88 & 84.6 & Baik sekali \\
\hline & Simpangan baku & 6,51 & 6,51 & 4,18 & 4,18 & 4,47 & 4,77 & Seragam \\
\hline & Koefisien variasi & 8,08 & 7,76 & 4,98 & 4,86 & 5,08 & 5,64 & Semakin baik \\
\hline
\end{tabular}

Uraian data Tabel 3 memberikan gambaran bahwa kemampuan pemahaman matematis siswa untuk setiap kelompok dalam lima kali pertemuan dapat dijelaskan seebagai berikut: (1) skor minimum dan skor maksimum yang dicapai siswa kelompok satu, dua, empat dan lima mengalami peningkatan, sedangkan kelompok tiga tidak mengalami peningkatan, namun mencapai rata-rata kemampuan baik sekali; (2) rata-rata kemampuan pemahaman matematis siswa mengalami peningkatan dari 81 menjadi 86, secara keseluruhan mencapai 84,6 dalam kategori baik sekali; (3) simpangan baku kemampuan pemahaman matematis siswa mengalami penurunan dari 6,51 menjadi 4,47, secara keseluruhan mencapai 4,77 dalam kategori seragam; (4) koefisien variasi kemampuan pemahaman mateatis siswa secara kelompok mengalami penurunan dari 8,08\% menjadi 5,08\%, secara keseluruhan mencapai 5,64\% menunjukkan semakin baik; dan (5) terdapat empat kelompok mencapai kemampuan pemahaman matematis siswa mencapai baik sekali, dan satu kelompok mencapai kategori baik. Secara keseluruhan hasil kerja kelompok siswa dalam menyelesaikan LKPD yang dipersiapkan guru dalam kualifikasi baik sekali.

Hasil ini memberikan gambaran bahwa penerapan model discovery learning dengan mempersiapkan bahan ajar, LKPD sebagai acuan belajar siswa, dan diterapkan berpusat pada siswa dalam mempelajari materi himpunan menciptakan suasana yang memotivasi siswa untuk belajar mengembangkan pengetahuannya secara bermakna.

\section{Kemampuan Pemahaman Matematis Siswa melalui Model Discovery Learning}

Kemampuan pemahaman matematis siswa diukur menggunakan instrumen tes berbentuk essay. Data kemampuan pemahaman matematis siswa diperoleh melalui hasil koreksi pekerjaan 32 siswa terhadap instrumen tes yang diberikan. Deskripsi hasil tes kemampuan pemahaman matematis siswa diuraikan pada Tabel 4.

Tabel 4. Deskripsi kemampuan pemahaman matematis (KPM) siswa kelas VIla SMP Negeri 1 kota Ternate setelah penerapan model discovery learning

\begin{tabular}{clcc}
\hline No & \multicolumn{1}{c}{ Statistik } & KPM siswa & Keterangan \\
\hline 1 & Skor minimum & 75 & Cukup \\
2 & Skor maksimum & 100 & Baik sekali \\
3 & Rata-rata & 90,72 & Baik sekali \\
4 & Simpangan baku & 8,74 & Cenderung seragam \\
5 & Koefisien variasi & $9,64 \%$ & Sangat baik \\
\hline
\end{tabular}


Berdasarkan data pada Tabel 4 di atas dapat dijelaskan: (1) skor minimum dan skor maksimum berturut-turut mencapai 75 dan 100, menunjukkan bahwa kemampuan pemahaman matematis siswa kelas VIIA SMP Negeri 1 Kota Ternate dalam mempelajari materi himpunan melalui penerapan model discovery learning mencapai kategori baik dan baik sekali; (2) skor rata-rata sebesar 90,72, menunjukkan bahwa secara klasikal kemampuan pemahaman matematis siswa kelas VIIA SMP Negeri 1 Kota Ternate pada materi himpunan mencapai 96,78\% kategori baik sekali; dan (3) simpangan baku dan koefisien variasi berturut-turut sebesar 8,74 dan 9,64\% yang menunjukkan bahwa kemampuan pemahaman matematis siswa kelas VIIA SMP Negeri 1 kota Ternate cenderung seragam. Hasil ini memberikan gambaran bahwa penerapan model discovery learning menciptakan terbentuknya keseragaman kemampuan pemahaman matematis siswa kelas VIIA SMP Negeri 1 kota Ternate dalam mempelajari materi himpunan.

Selanjutnya, kualifikasi kemampuan pemahaman matematis siswa kelas VIIA SMP Negeri 1 Kota Ternate setelah penerapan model discovery learning dianalisis berdasarkan tingkat pemahaman matematis siswa dalam mempelajari materi himpunan. Hasil analisis kemampuan pemahaman matematis siswa tersebut disesuaikan berdasarkan pedoman acuan patokan (PAP) skala lima, sebagaimana diuraikan pada Tabel 5.

Tabel 5. Kualifikasi kemampuan pemahaman matematis (KPM) siswa kelas VIla SMP Negeri 1 kota Ternate setelah penerapan model discovery learning

\begin{tabular}{ccccc}
\hline No & Interval KPM & Frekuensi & Persentase & Kualifikasi \\
\hline 1 & $90-100$ & 19 & $59,37 \%$ & Baik sekali \\
2 & $80-89$ & 9 & $28,13 \%$ & Baik \\
3 & $70-79$ & 4 & $12,50 \%$ & Cukup \\
& Jumlah & 32 & $100 \%$ & \\
\hline
\end{tabular}

Berdasarkan data Tabel 5 dapat dijelaskan bahwa terdapat: 19 siswa $(59,37 \%)$ mencapai kualifikasi kemampuan pemahaman matematis dalam kategori baik sekali, 9 siswa $(28,13 \%)$ mencapai kualifikasi kemampuan pemahaman matematis dalam kategori baik, dan 4 siswa (12,50\%) dalam kualifikasi cukup. Capaian kualifikasi ini menunjukkan bahwa sebagian besar siswa kelas VIIA SMP Negeri 1 kota Ternate telah berkemampuan pemahaman matematis pada materi himpunan setelah diterapkan model discovery learning. Artinya, penerapan model discovery learning dapat menciptakan terbentuknya kemampuan pemahaman matematis siswa dalam mempelajari materi himpunan. Ditinjau berdasarkan skor ketuntasan belajar siswa dengan KKM sebesar 75, menunjukkan terdapat 28 siswa $(87,50 \%)$ mencapai ketuntasan dalam mempelajari materi himpunan, dan 4 siswa $(12,50 \%)$ belum mencapai ketuntasan belajar.

Hasil uji perbedaan kemampuan pemahaman matematis siswa setelah penerapan model discovery learning yang dibandingkan dengan skor KKM 75, diperoleh nilai thitung sebesar 10,166 dengan signifikansi 0,000 lebih kecil dari taraf kesalahan $a=0,05$. Hasil ini menunjukkan bahwa terdapat perbedaan yang signifikan kemampuan pemahaman matematis siswa pada materi himpunan setelah penerapan model discovery learning dengan skor KKM yang ditentukan sekolah. Perbedaan ini memberikan gambaran bahwa penerapan model discovery learning secara signifikan dapat meningkatkan kemampuan pemahaman matematis siswa kelas VIIA SMP Negeri 1 kota Ternate dalam mempelajari materi himpunan.

\section{PEMBAHASAN}

Penerapan model discovery learning menciptakan siswa termotivasi untuk mengikuti proses pembelajaran, aktif mengkaji materi himpunan yang dipelajarinya, dan berusaha menemukan jawaban terhadap soal latihan yang dipersiapkan dalam LKPD. Temuan ini relevan dengan uraian NCTM (2005) bahwa penerapan model discovery laerning menuntun siswa untuk mencari tahu, bukan diberitahu dan menekankan kemampuan berbahasa sebagai alat komunikasi, pembawa pengetahuan dan berpikir logis, sistematis, dan kreatif. Kenyataan ini didukung adanya peningkatan aktivitas guru dan siswa dalam menjalankan pembelajaran discovery learning dalam kategori baik. 
Semakin meningkatnya aktivitas siswa dalam setiap pertemuan mendorong terjadinya peningkatan skor maksimum, skor minimum, dan skor rata kemampuan pemahaman matematis siswa. Sebaliknya, peningkatan aktivitas guru dan siswa selama penerapan model discovery learning menurunkan simpangan baku dan koefisien variasi kemampuan pemahaman matematis siswa secara klasikal dalam mempelajari materi himpunan. Penurunan simpangan baku dan koefisien variasi memberikan gambaran bahwa penerapan model discovery learning mendorong terciptanya keseragaman dan semakin baiknya kemampuan pemahaman matematis siswa dalam mempelajari materi himpunan.

Penerapan model discovery learning mengantarkan 19 siswa $(59,37 \%)$ mencapai kualifikasi kemampuan pemahaman matematis dalam kategori baik sekali, 9 siswa $(28,13 \%)$ mencapai kualifikasi kemampuan pemahaman matematis dalam kategori baik, dan 4 siswa (12,50\%) dalam kualifikasi cukup. Capaian ini menunjukkan bahwa sebagian besar siswa kelas VIIA SMP Negeri 1 kota Ternate telah berkemampuan pemahaman matematis pada materi himpunan setelah diterapkan model discovery learning. Penerapan model discovery learning dapat menciptakan terbentuknya kemampuan pemahaman matematis siswa dan menciptakan ketuntasan belajar siswa dalam mempelajari materi himpunan. Artinya, penerapan model discovery learning secara signifikan dapat meningkatkan kemampuan pemahaman matematis siswa kelas VIIA SMP Negeri 1 kota Ternate dalam mempelajari materi himpunan. Kesimpulan ini sejalan dengan uraian Bicknell \& Hoffman (2000), discovery menekankan pada ditemukannya konsep atau prinsip yang sebelumnya tidak diketahui. Discovery memperhadapkan masalah hasil rekayasa guru kepada siswa, sehingga siswa harus mengerahkan seluruh pikiran dan keterampilannya untuk mendapatkan temuan-temuan didalam masalah itu melalui proses penelitian.

\section{KESIMPULAN}

Berdasarkan hasil dan pembahasan penelitian di atas, dapatlah diajukan beberapa kesimpulan sehubungan dengan kemampuan pemahaman matematis siswa kelas VIIA SMP Negeri 1 kota Ternate dalam mempelajari materi himpunan setelah diterapkan model discovery learning, yaitu:

1. Aktivitas guru dalam menerapkan model discovery learning bahwa guru telah melakukan perencanaan pengajaran secara baik dengan mempersiapkan RPP, bahan ajar, dan LKPD yang berisi petunjuk dan soal latihan dengan baik, serta menjalankan semua tahapan pembelajaran secara berurutan dan terlaksana dengan sangat baik, sehingga menciptakan siswa termotivasi untuk mengikuti proses pembelajaran, aktif mengkaji materi himpunan yang dipelajarinya, dan berusaha menemukan jawaban terhadap soal latihan yang dipersiapkan dalam LKPD. Tingginya motivasi dan keaktivan siswa mendorong aktivitas siswa mengalami penigkatan dan mencapai kategori baik sekali.

2. Rata-rata kemampuan pemahaman matematis siswa kelas VIIA SMP Negeri 1 kota Ternate pada materi himpunan mencapai 96,78\% kategori baik sekali. Terdapat 19 siswa $(59,37 \%)$ mencapai kualifikasi kemampuan pemahaman matematis dalam kategori baik sekali, 9 siswa $(28,13 \%)$ mencapai kualifikasi kemampuan pemahaman matematis dalam kategori baik, dan 4 siswa $(12,50 \%)$ dalam kualifikasi cukup. Selain itu, terdapat 28 siswa $(87,50 \%)$ mencapai ketuntasan dan 4 siswa (12,50\%) belum mencapai ketuntasan dalam mempelajari materi himpunan.

3. Penerapan model discovery learning secara signifikan dapat meningkatkan kemampuan pemahaman matematis siswa kelas VIIA SMP Negeri 1 kota Ternate dalam pembelajaran matematika materi himpunan. 


\section{REKOMENDASI} berikut:

Memperhatikan hasil penelitian ini, maka dapat diajukan beberapa rekomendasi sebagai

1. Guna peningkatan kualitas pembelajaran yang berpusat pada siswa sesuai permintaan kurikulum 2013, diperlukan kemampuan guru dalam mengelolah proses pembelajaran, mempersiapkan perangkat pembelajaran (RPP, bahan ajar, dan LKPD) secara baik kebutuhan, dan menguasai penerapan langkah-langkah model pembelajaran, dan memfasilitasi belajar siswa baik secara individu maupun kelompok.

2. Mencapai terciptanya kondisi belajar siswa yang aktif dan interaktif, diperlukan kompetensi intelektual guru terhadap materi yang dipelajari yang senantiasa diarahkan mencapai indikator dan tujuan pembelajaran.

3. Menuju pencapaian hasil pembelajaran yang maksimal, dibutuhkan persiapan perangkat pembelajaran yang relevan dengan tahapan pembelajaran, kemampuan menciptakan efektif dan efisien proses pembelajaran dari guru sebagai pengatur dan pengelola kelas.

4. Mengingat model discovery learning mengarahkan siswa untuk mencari tau, maka diperlukan persiapan sekolah dan orang tua dalam menyediakan buku sumber kepada peserta didik.

5. Memperhatikan lambatnya kecepatan siswa dalam membaca bermakna untuk menggali informasi penting terhadap materi yang dipelajarinya, diperlukan perhatian sekolah dan guru dalam pembimbingan dan pembentukan budaya literasi membaca dan belajar bagi peserta didik di lingkungan sekolah dan masyarakat.

6. Menumbuhkan melek ilmu pengetahuan kepada siswa diperlukan strategi terciptanya motivasi intriksik siswa dalam memahami pentingnya kebutuhan adanya ilmu pengetahuan bagi kelangsungan hidup masa depan.

\section{UCAPAN TERIMAKASIH}

Terima kasih kepada siswa kelas VIIA dan Kepala Sekolah SMP Negeri 1 kota Ternate, Bapak Mustamin Hamzah, S. Pd., M.M yang telah mengijinkan dan memfasilitas selama proses penelitian.

\section{DAFTAR PUSTAKA}

Afrilianto, M. (2012). Peningkatan pemahaman konsep matematika dan kompetensi strategi matematis siswa smp dengan pendekatan metaphorical thinking. Jurnal Infinity Pendidikan Matematika. STIKIP Siliwangi, 1(2), 196-197.

Alma, B., et al. (2010). Guru profesional menguasai metode dan terampil mengajar. Bandung: Penerbit Alfabeta.

Bakar, M. T, Suryadi, D., \& Darhim. (2018). The Association between concept understanding and reasoning ability in mathematics; An Analysis of DNR- Based instruction model, Journal of Physics: Conference Series. IOP Conf. series 1088012107

Bakar, M. T, (2018) Peningkatan kemampuan pemahaman konsep dan penalaran serta disposisi matematis mahasiswa pendidikan guru sekolah dasar melalui model dnr-based instruction. Disertasi. Pada Program Studi Pendidikan Matematika Sekolah Pascasarjan Pendidikan Matematika Universitas Pendidikan Indonesia. Bandung. Tidak dipublikasikan.

Bakar M. T, Suryadi D, \& Darhim. (2020). Improvement of college student mathematical concept understanding through dnr-based instruction models. DOI 10.5220/0008899101900193. Proceding of the 1st International Conference on Teaching and Learning (ICTL 2018), Page 
190-193. ISBN: 978-989-758-439-8. Copyright@ 2020 by SCITEPRESS-Science and Technologi Publications, Lda. All rights reserved.

Borthick, F., \& Jones, D. R. (2000). Motivation for collaborative online learning invention and its application in information systems security course. Issues in Accounting Education, 15(2), 181-210.

Dewiatmini, P. (2010). Upaya meningkatkan pemahaman konsep matematika pada pokok bahasan himpunan siswa kelas vii a smp negeri 14 yogyakarta dengan penerapan model pembelajaran kooperatif tipe stad. Skripsi, Universitas Negeri Yogyakarta.

Kementerian Pendidikan dan Kebudayaan. 2014. Peraturan Menteri Pendidikan dan Kebudayaan Republik Indonesia nomor 103 tahun 2014 tentang Kurikulum 2013 Sekolah Menengah Atas/Madrasah Aliyah

NCTM. 2005. How students learn: History, mathematics, and science in the classroom. Washington, DC: National Academies Press.

Rahmawati, D. 2011. Upaya meningkatkan pemahaman konsep matematika dengan menggunakan metode pemberian tugas dan resitasi pada kelas xi ipa sma negeri 1 seyegen sleman yogyakarta. Skripsi, Universitas Negeri Yogyakarta.

Sugiyono. 2015. Metode penelitian dan pengembangan reseach and development. Bandung: Alfabeta.

Sumarmo, U (2013). Berpikir dan disposisi matematik serta pembelajarannya. Kumpulan makalah Jurusan Pendidikan Matematika dan IImu Pengetahuan Alam, UPI: Bandung

Trianto. 2007. Model-model pembelajaran inovatif berorientasi konstruktivistik. Jakarta: Prestasi Pustaka Publiser. 